\title{
Eyjafjallajökull Volcanic Eruption: Ice Nuclei and Particle Characterization
}

\author{
Franco Belosi, Gianni Santachiara, Franco Prodi \\ Institute of Atmospheric Science and Climate (ISAC), National Research Council, Bologna, Italy \\ E-mail: g.santachiara@isac.cnr.it \\ Received March 8, 2011; revised March 21, 2011; accepted March 28, 2011
}

\begin{abstract}
The Eyjafjallajökull 2010 eruption was an extraordinary event in that it led to widespread and unprecedented disruption to air travel over Europe - a region generally considered to be free from the hazards associated with volcanic eruptions, excluding the extreme south influenced by Mt. Etna. In situ measurements were performed at the research centre of the National Research Council (CNR) area of Bologna $\left(44^{\circ} 31^{\prime} \mathrm{N} ; 11^{\circ} 20^{\prime}\right.$ E), an urban background site, in order to contribute to knowledge concerning the impact of the volcanic emission.Aerosol size distributions measured with a Differential Mobility Particle Sizer (DMPS) and an Optical Particle Counter (OPC) show an increase in concentration of the accumulation and coarse fraction during the transit of the ash cloud, with respect to the subsequent period of the event, while particles smaller than $0.3 \mu \mathrm{m}$ seem not to be affected by volcanic ash. Ice nuclei measured in the sampled air during and after the ash cloud transit, show an higher concentration during the ash cloud transit, with a ratio of about 1:110 with respect to the aerosol number concentration measured with the OPC. The elemental composition of aerosol particles, performed with SEM-EDX, gives about 30\% of the inorganic coarse particles (geometric diameter larger than $1 \mu \mathrm{m}$ ) of volcanic origin on the 20 April. Si and Al concentrations result prevalently much higher than $\mathrm{Ca}$ and $\mathrm{Fe}$ ones. A large number of particles contained sulphur, indicating secondary processes of sulphate/sulphuric acid formation due to sulphur dioxide oxidation during transport in the volcanic plume.
\end{abstract}

Keywords: Ice Nuclei, Nucleation, Supersaturation, Volcanic Ash

\section{Introduction}

Volcanic clouds are a suspension of particles similar to meteorological clouds, generated by volcanic activity and dispersed into the atmosphere. They include volcanic ashes, hydrometeors (drops, ice crystals, hails), vapours and gases. After the emission of ashes, gases and vapours, there occur microphysical processes such as homogeneous or heterogeneous nucleation, hygroscopic growth, coagulation, condensation, adsorption of species on to the surfaces of other particles, chemical reactions (gas-to-particles reactions and aqueous phase reactions), as well as dry and wet deposition. As a consequence, particle size distribution changes significantly with the distance from the event. Droplets form as temperature decreases during the rise, and sometimes freeze. The release of latent heat during freezing affects plume buoyancy and maximum plume height. Besides entrained tropospheric water vapor, sources of water available for volcanic cloud ice include magma, various hydrospheric reservoirs (ocean, crater lakes, glaciers, groundwater) and hydrothermal systems [1-3]. Ice in volcanic clouds enhances ash fallout by forming composite aggregates and may be dominant, subordinate or subequal to ash in terms of mass in volcanic clouds. Rose et al., [4] reports recent cases where ice was dominant (Rabaul, in Papua New Guinea, 1994 eruption; Hekla, in Iceland, 2000 eruptions), cases where ice was clearly subordinate (Augustine, in Alaska, 1986; Mount Spurr, in Alaska, 1992; Cleveland, in Alaska, 2001; Kluychevskoy, in Kamchatka, 1994), and cases where there was a subequal proportion of ice and ash in volcanic clouds (Pinatubo, in Philippines 1991, El Chichón, in Mexico 1982). More examples of ash dominant volcanic clouds are found at all latitudes higher than $40^{\circ}$, which suggests that tropospheric water vapour which is much higher at tropical 
latitudes, influences volcanic cloud ice through the entrainment process [5].

Aerosol particles that catalyze the formation of ice crystals in clouds are called Ice Nuclei (IN), and they can form ice through homogeneous or heterogeneous processes. The homogeneous nucleation process involves only pure water or solution droplets, and depends on the mass and temperature of liquid water, or in aqueous solution, on water activity [6]. Ice will not homogeneously form from pure solution droplets, no matter how diluted, at temperatures greater than about $-38^{\circ} \mathrm{C}$ [7].

Four heterogeneous nucleation mechanisms are distinguished for atmospheric ice formation: deposition (direct transition from vapour to solid on a foreign particle below water saturation), condensation-freezing (ice-phase forms as water vapour condenses on cloud condensation nuclei at $\mathrm{T}<0^{\circ} \mathrm{C}$ and afterwards freezes), contact-freezing and immersion-freezing. Heterogeneous freezing occurs at lower ice-saturation ratios and a higher temperature than homogeneous freezing.

The IN concentrations in the atmosphere constitute a very small fraction of the aerosol population. Rosinski [8] proposes an approximate ratio of $1: 10^{6}$, while Szyrmer and Zawadzki [9] suggest that the concentration of IN in a typical cloud $\left(\mathrm{T}=-10^{\circ} \mathrm{C}\right)$ is about seven to nine orders of magnitude less than the total aerosol.

Concerning volcanic clouds, there are conflicting views in the literature regarding the effectiveness of volcanic ash as IN, with some investigators concluding that volcanic emissions contain abundant IN [10-12], while others which suggest that at least some active volcanoes do not release IN into the atmosphere [13-16].

Durant et al., [17] performed freezing experiments with water drops containing volcanic ash. Silica-rich and silica-poor particles were considered, with the authors suggesting that fine ash-particles (defined as particles with equivalent diameters between 1 and $1000 \mu \mathrm{m}$ ) will exhibit an onset of freezing between 250 - $260 \mathrm{~K}$, finding very little difference between the considered particles. Such results imply that other physical properties such as surface morphology, defects and active sites, play an important role, implying that volcanic clouds are IN-rich relative to meteorological clouds. It is important to highlight that the modality of the experiment (particles put on the surface or inside the volume of the distilled water drops) means that only contact nucleation is considered.

In the case of the Eyjafjallajökull volcano $\left(63^{\circ} 38^{\prime} \mathrm{N}\right.$, $19^{\circ} 36^{\prime} \mathrm{W}$, summit $1666 \mathrm{~m}$ a.s.1.), the eruption started on 20 March 2010. The first phase was characterized by an effusive eruption that produced lava flows on the ground and only minor emissions into the atmosphere. According to Burton et al., [18], the $\mathrm{SO}_{2}$ and $\mathrm{HF}$ gas fluxes produced by the eruption were about 3000 and 30 tonnes per day, respectively, and the gas composition was very rich in $\mathrm{H}_{2} \mathrm{O}\left(>80 \%\right.$ by mole; $<15 \% \mathrm{CO}_{2}$ and $\left.<3 \% \mathrm{SO}_{2}\right)$. Sulphur dioxide is often used as tracer for volcanic plumes [19].

On 14 April an explosive eruption of the volcano started with the ash plume reaching a height of $9.5 \mathrm{~km}$ on the first day, but later $5-7 \mathrm{~km}$. There was frequent lightning (IES: Institute of Earth Sciences, University of Iceland, http://www.earthice.hi.is/).

The eruption started beneath a glacier, which intensified its explosiveness because water vapour was produced by the interaction of hot volcanic material with ice. The explosive eruption continued with varying intensity for over one month. A high pressure system in the south of Iceland on 14/15 April and, later, in western Scandinavia, favoured the transport with north-westerly winds of large amounts of erupted material, mostly volcanic ash, water vapour and $\mathrm{SO}_{2}$, across the North-Eastern Atlantic towards the British Isles, Scandinavia and, later on, to Central Europe.

The aim of this study is to employ measurements of aerosol size distribution, elemental composition and IN concentration in air, to ascertain whether some of the volcanic ash reached ground level.

\section{Experimental}

At the National Research Council (CNR) area of Bologna, an urban background site, was operating a sampling station located on the roof (15 $\mathrm{m}$ above ground level) of the Institute of Atmospheric Science and Climate (ISAC) for instrument comparison purposes. The sampling station was equipped with a DMPS system (DMA-L Model 5.500, Condensation Particle Counter Model 5.403, Grimm $\mathrm{GmbH}$ ) with aerosol size resolution between 0.010 and $1 \mu \mathrm{m}$, and an OPC (Dust Monitor 1.108, Grimm $\mathrm{GmbH}$ ) with size resolution between 0.3 and 20 $\mu \mathrm{m}$. Aware of a possible transit of the volcano cloud over Bologna, data were recorded from 19 April. Unfortunately, a failure in the power supply stopped the measurements during the afternoon, with recording resumed the following day. Nevertheless, even if the data were not continuosly collected, it was possible to observe differences in the aerosol size distribution in the considered period (20-22 April 2010).

Sampling of aerosol particles was performed on the roof of ISAC simultaneously with the measurements of the size distribution. Various aerosol fractions (PM1, PM2.5, PM10) and total suspended particles (TSP) were sampled on nitrocellulose membrane (Millipore HABG04700, nominal porosity $0.45 \mu \mathrm{m}$ ). Aerosol fractions were sampled by inserting different sampling heads ( $1 \mu \mathrm{m}, 2.5 \mu \mathrm{m}$, and $10 \mu \mathrm{m}$ cut-point-Standard EN12341, 
TCR Tecora) in front of the filter. Meteorological data (air temperature, wind speed, pressure) were also recorded.

Concentrations of IN were detected by the membrane filter technique, using a replica of the Langer dynamic developing chamber [20] housed inside a refrigerator. Use of the dynamic chamber circumvents some of the problems arising from the use of the static chamber, e.g. that the moisture supply under static conditions may be rather inadequate at a filter surface both in overcoming the effect of hygroscopic particles and in activating all potential ice nuclei.

For each sampling, PM1, PM2.5, PM10 and TSP filters were cut into four pieces, and one piece for each fraction was inserted into the same metal plate, previously covered with a smooth surface of paraffin. The four pieces of different filters (PM1, PM2.5, PM10 and TSP) were exposed to water vapour for about half an hour at constant supersaturation. This allowed the simultaneous development of PM1, PM2.5, PM10 and TSP ice nuclei.

The supersaturations $\left(S_{\text {ice }}, S_{\mathrm{w}}\right)$ are calculated theoretically from vapour pressures of ice and water at the considered temperatures [21]. Taking into account the accuracy of the air and sample temperature sensors, and of temperature control systems, an experimental uncertainty of about $6 \%$ for $S_{\text {ice }}$ and $S_{\mathrm{w}}$ was estimated. The details are reported in Santachiara et al., [22]. Table 1 shows the operating conditions.

The aerosol particles collected on TSP filter on 20 April were examined by Scanning Electron Microscopy (SEM) coupled with an energy dispersive X-ray (EDX) detector. One sector of TSP filter was mounted on an aluminium holder using a carbon conductive adhesive tape before the graphite coating. Semi-quantitative elemental analyses of randomly selected particles were obtained.

\section{Results and Discussion}

A high pressure system in the south of Iceland on 14/15 April and, later, western Scandinavia favoured the transport by north-westerly winds of large amounts of erupted material, mostly volcanic ash, water vapour, and sulphur dioxide $\left(\mathrm{SO}_{2}\right)$, across the North-Eastern Atlantic towards the British Isles, Scandinavia and, later on, to

Table 1. Operating conditions of IN measurements.

\begin{tabular}{cccc}
\hline$T_{\text {air }},{ }^{\circ} \mathrm{C}$ & $T_{\text {filter }},{ }^{\circ} \mathrm{C}$ & $S_{\text {ice }}, \%$ & $S_{\mathrm{w}}, \%$ \\
\hline-17 & -18 & 9.8 & -7.7 \\
-17 & -19 & 20.8 & 0.45 \\
\hline
\end{tabular}

Central Europe [23].

The evidence of the arrival of the aerosol cloud over Italy can be validated in various ways. Five-day backward trajectories (http://ready.arl.noaa.gov/HYSPLIT.php) arriving in Bologna at medium (1000 m a.s.l.) and high level (2000 m a.s.1.) on 20 April show air masses coming from Iceland, while on 22 April the origin of the air masses is completely different (Figure 1).

Since on 20 April the air masses came from Iceland at 1-2 km height and the boundary layer was around 1600 m (CALMET simulation, http://www.arpa.emr.it/sim), a mixing with the surface was possible. Horizontal winds at $850 \mathrm{hPa}$ on 20 April 2010 came from the North-West

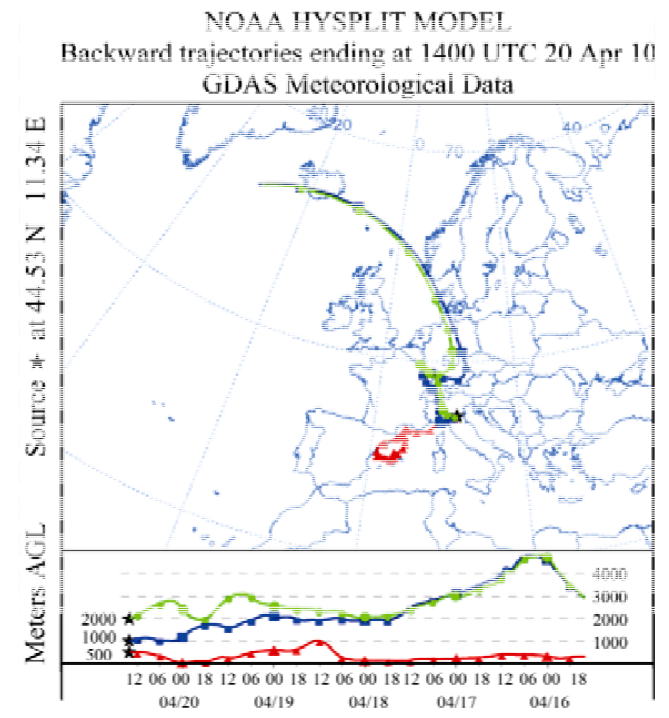

(a)

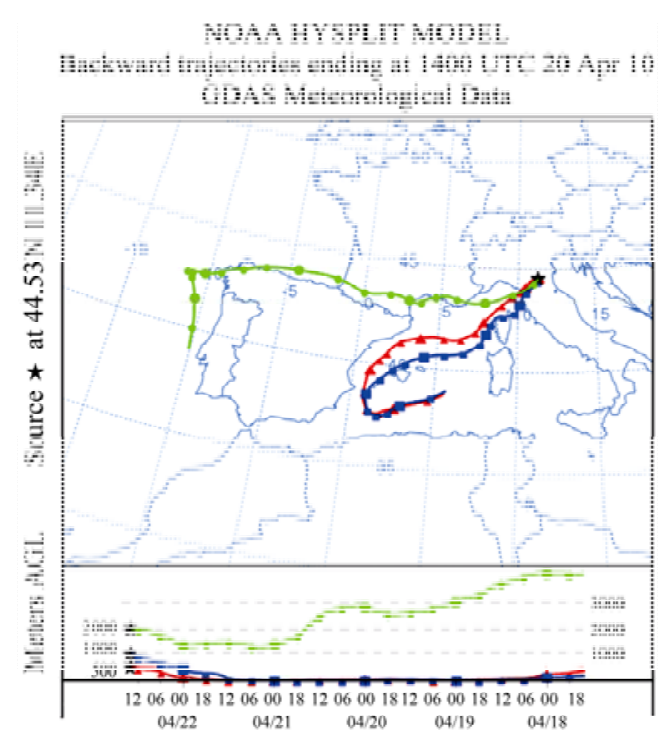

(b)

Figure1. Five day back trajectories on 20 April (a) and 22 April (b). 
sector, while on 22 April arrived from the West sector, as can be inferred from BOLAM (BOlogna Limited Area

Model, www.meteoliguria.it/MAP/BOLAM).

The ash front was observed by lidar observations in Florence from 19 April to 20 April (Institute of Applied Physics, http://lidarmax.altervista.org/englidar/home.php). Further evidence of the volcanic cloud travelling from northern towards southern Italy on these days can be inferred from an examination of the aerosol optical depth (AOD) from the EARLINET observations [24], with a peak at 12 am on 20 April and from AERONET Modena station (443ㅇ $\mathrm{N}, 10^{\circ} 56^{\prime} \mathrm{E}$, http://aeronet.gsfc.nasa.gov/) which shows in the same day an increase in the AOD at $440 \mathrm{~nm}$ wavelength (averaged value 0.419). In the following days (21 and 22 April) the AOD averaged values are lower $(0.390$ and 0.330 , respectively). It could be excluded that this variation was due to local emissions, as the daily PM10 averaged concentration values in the urban area do not change in the sampling period.

Table 2 shows the two-hour averaged particle number concentration in different size fractions calculated from the samplings taken simultaneously with the ice nuclei measurements (averaging time from $1 \mathrm{pm}$ to $3 \mathrm{pm}$ ). The aerosol fine fraction was obtained by means of DMPS measurements, while accumulation and coarse fractions were provided by OPC measurements.

It can be seen that measurements show an increase in concentration of the accumulation and coarse fractions (the latter very pronounced), on 20 April with respect to 22. On the other hand, the number concentration of particles in the fine fraction (diameter lower than $0.3 \mu \mathrm{m}$ ), a little higher on the 22 compared with the 20 April, seems to show that the abundance of particles smaller than 0.3 $\mu \mathrm{m}$ was not affected by volcanic ash.

The increase in large particles with the arrival of the ash plum, followed by a subsequent decrease, and the fact that the abundance of particles smaller than $0.3 \mu \mathrm{m}$ was not affected by volcanic ash, is shown also by Flentje et al., [23] at the Global Atmosphere Watch (GAW) Zugspitze/Hohenpeissenberg station (Germany).

Figure 2 shows the two averaged volume aerosol size distributions obtained by the OPC on 20 and 22 April. The data are averaged from $1 \mathrm{pm}$ to $3 \mathrm{pm}$ on both days. The curves clearly show a mode in the coarse fraction on the first day (20/04/2010), which becomes less evident on 22 April.

Table 2. Averaged aerosol particle number concentration in different size fractions $\left(\mathrm{cm}^{-3}\right)$.

\begin{tabular}{cccc}
\hline Period & $\begin{array}{c}\text { Fine fraction } \\
0.01-0.3 \mu \mathrm{m}\end{array}$ & $\begin{array}{c}\text { Accumulati } \\
\text { on fraction } \\
0.3-1 \mu \mathrm{m}\end{array}$ & $\begin{array}{c}\text { Coarse } \\
\text { fraction } \\
>1 \mu \mathrm{m}\end{array}$ \\
\hline 20 April $(1 \mathrm{pm}-3 \mathrm{pm})$ & 9797 & 77.4 & 1.3 \\
22 April $(1 \mathrm{pm}-3 \mathrm{pm})$ & 13552 & 40.4 & 0.3 \\
\hline
\end{tabular}

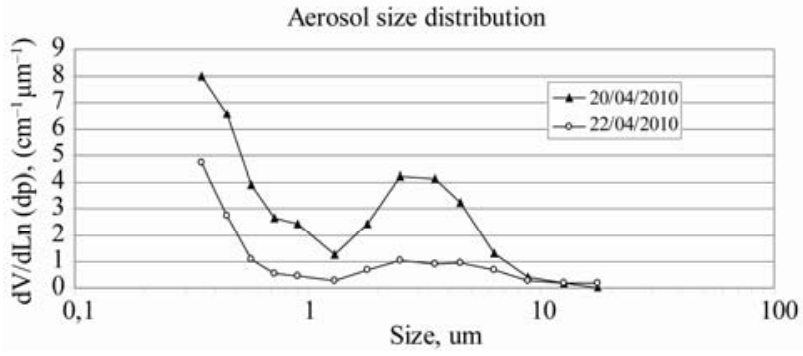

Figure 2. Volume aerosol size distribution average from 1 pm to 3 pm on 20 and 22 April.

The fitting of the volume size distribution with a bimodal lognormal distribution function shows a first unresolved mode, for both days, at around $0.2-0.3 \mu \mathrm{m}$ (volume median diameter), and a second mode with a volume median diameter of $3 \mu \mathrm{m}$ (geometric standard deviation of 2.5 and 3.1, on 20 April and 22 April, respectively). Moreover, the fraction of particles in the second mode is $68 \%$ on 20 April, and only $18 \%$ on 22 April. A similar size distribution is reported by Brunner [25] at Junghfraujoch (3600 m). Therefore, also combining this with the backward trajectories analysis, it can be confidently assumed that volcanic ash reached ground level.

Table 3 and Table 4 show the measured concentrations of IN, considering two values of $S_{\text {ice }}$ and $S_{\mathrm{w}}$, in the aerosol sampled on 20 and 22 April, sized according to the aerodynamic diameter.

Measurements below water saturation $\left(S_{\text {ice }}=9.8 \% ; S_{\mathrm{w}}\right.$ $=-7.7 \%$ ) should allow the detection of deposition (sorption) nuclei, while those above water saturation $\left(S_{\text {ice }}\right.$ $\left.=20.8 \% ; S_{\mathrm{w}}=0.45 \%\right)$ indicate the detection also ofcondensation-freezing nuclei. It must be noted that IN concentrations point to different behaviours between the aerosol sampled on 20 April and on 22 April, day on which back trajectories and lidar observation show that the influence of the volcanic emission should be negligible. As a matter of fact, while in conditions of subsaturation with respect to water, the concentration are similar for both 20 and 22 April samples, at supersaturation both

Table 3. Concentration of particles $\left(\mathrm{m}^{-3}\right)$ active as IN in the considered fractions (20 April 2010).

\begin{tabular}{ccccc}
\hline & $\mathrm{IN}_{\mathrm{PM} 1}$ & $\mathrm{IN}_{\mathrm{PM} 2.5}$ & $\mathrm{IN}_{\mathrm{PM} 10}$ & $\mathrm{IN}_{\mathrm{TSP}}$ \\
\hline$S_{\text {ice }}=9.8 \% ; S_{\mathrm{w}}=-7.7 \%$ & 13 & 25 & 40 & 71 \\
$S_{\text {ice }}=20.8 \% ; S_{\mathrm{w}}=0.45 \%$ & 461 & 539 & 462 & 704 \\
\hline
\end{tabular}

Table 4. Concentration of particles $\left(\mathrm{m}^{-3}\right)$ active as IN in the considered fractions (22 April 2010).

\begin{tabular}{ccccc}
\hline & $\mathrm{IN}_{\mathrm{PM} 1}$ & $\mathrm{IN}_{\mathrm{PM} 2.5}$ & $\mathrm{IN}_{\mathrm{PM} 10}$ & $\mathrm{IN}_{\mathrm{TSP}}$ \\
\hline$S_{\text {ice }}=9.8 \% ; S_{\mathrm{w}}=-7.7 \%$ & 38 & 41 & 68 & 53 \\
$S_{\text {ice }}=20.8 \% ; S_{\mathrm{w}}=0.45 \%$ & 64 & 72 & 96 & 95 \\
\hline
\end{tabular}


with respect to ice $\left(S_{\text {ice }}=20.8 \%\right)$ and water $\left(S_{\mathrm{w}}=0.45 \%\right)$, there is a marked increase of IN for the 20 April sample, and only a moderate increase for the 22 April sample.

Previous measurements [22] performed in a rural area (S. Pietro Capofiume, near Bologna, July 2007) gave a lower $\mathrm{IN}_{\mathrm{TSP}}$ concentration $\left(110 \mathrm{~m}^{-3} ; S_{\text {ice }}=20 \% ; S_{\mathrm{w}}=\right.$ $2 \%$ ) than the value measured on 20 April $\left(704 \mathrm{~m}^{-3}\right)$, although the supersaturation in this case is lower $\left(S_{\text {ice }}=\right.$ $\left.20.8 \% ; S_{\mathrm{w}}=0.45 \%\right)$. At this supersaturation, the 20 April filter shows a ratio of IN (measured in the total suspended particles) to aerosol number concentration measured with optical counter (particle size larger than $0.3 \mu \mathrm{m}$ ), of about 1:110, while in the rural area of $\mathrm{S}$. Pietro Capofiume the mean value was 1:1700. For the 22 April filter, the same ratio is about 1:430.

The different behaviour of aerosol at low water supersaturation should indicate some changes in the physical and chemical properties of the particles. One of the reasons of the marked increase in the IN concentration for the 20 April sample at $S_{\mathrm{w}}>0$ could be the presence of insoluble particles coated by soluble compounds, which favour the growth of aerosol diameter and increase the possibility of the freezing. As a matter of fact, larger samples have a higher freezing temperature than smaller ones, both in homogeneous and heterogeneous nucleation $[26,6]$.

In support of this statement, Brunner [25] measured an increase of soluble compounds at Junghfraujoch (3600 m), i.e. $\mathrm{SO}_{4}^{2-}, \mathrm{NH}_{4}^{+}, \mathrm{NO}_{3}^{-}, \mathrm{Ca}^{2+}, \mathrm{Mg}^{2+}, \mathrm{K}^{+}$during Eyjafjallajökull eruption, with respect to values prior to the event.

Using ground-based observations, Rolf et al., [27] detected the ash cloud a few days after the April eruptions with a lidar over Western Germany, Jülich $\left(50^{\circ} 54^{\prime} \mathrm{N}\right.$, $6^{\circ} 24^{\prime}$ E). Their measurements showed condensation of ice on the ash particles and the growth of induced cirrus clouds. Lidar measurements highlight areas with high depolarization, which are indicative of ice particles.

As far as the elemental composition of aerosol parti- cles is concerned, in order to try to distinguish ash particles from local crustal or anthropogenic sources, the present study took into account the chemical analysis of rocks from the Eyjafjallajökull 2010 eruptions (Institute of Earth Sciences - University of Iceland). Inorganic coarse particles on the filter were considered to be ash particles in the presence of $\mathrm{Si}, \mathrm{Fe}, \mathrm{Mg}, \mathrm{Al}, \mathrm{Ca}$, and in addition $\mathrm{K}$, or $\mathrm{Ti}$, or $\mathrm{S}$ or $\mathrm{Na}$, even in small concentrations.

Figure 3 and Figure 4 show two particles and the corresponding EDX spectrum, collected on 20 April, which could be considered volcanic ash according to the above mentioned criteria.

With these constraints, it was found here that $30 \%$ of the inorganic coarse particles (geometric diameter larger than $1 \mu \mathrm{m}$ ) could be considered to be volcanic origin on 20 April. The $\mathrm{Si}$ and $\mathrm{Al}$ concentrations were mostly much higher than $\mathrm{Ca}$ and $\mathrm{Fe}$ ones. About $28 \%$ of the ash particles examined and about $50 \%$ of the particles with geometric diameter less than $1 \mu \mathrm{m}$ contain sulphur, probably indicating adsorption of S-rich particles onto the coarse particles [28-30]. The small particles in volcanic ash plumes should be typically composed largely of sulphuric acid.

\section{Conclusions}

Backward trajectories, lidar observations and aerosol optical depth measurements performed by various research centers, confirm that the ash cloud affected Italy on 20 April.

Measurements of aerosol size distribution performed with a DMPS and an OPC show an increase in concentrations of the accumulation and coarse fraction (the latter, very marked), on 20 April with respect to 22 April, when, on the basis of five days back trajectories and lidar observations, the influence of volcanic emission should be negligible. On the other hand the number concentration of particles in the fine fraction (particle diameter less
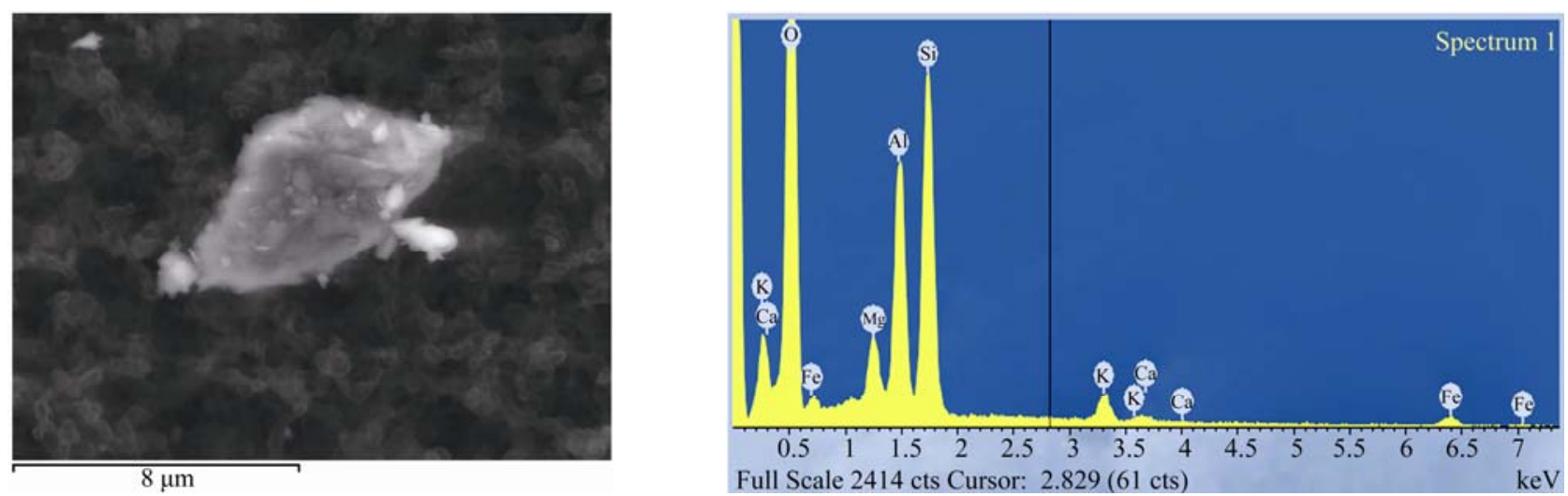

Figure 3. SEM picture and elemental analysis of a particle collected on 20 April. 

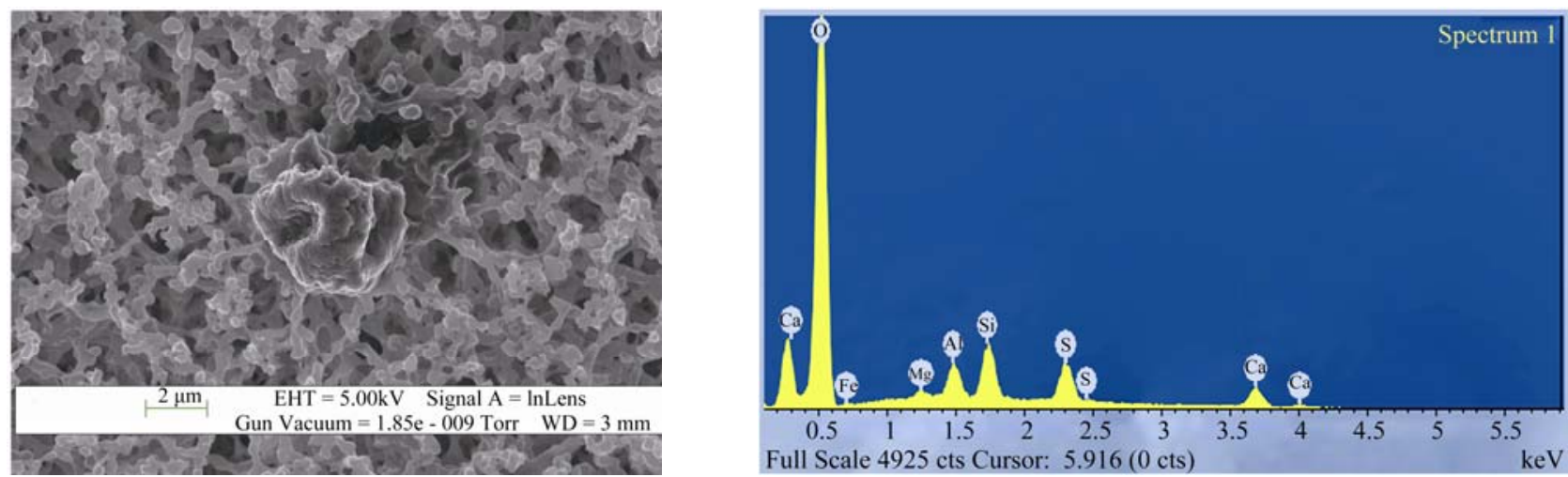

Figure 4. SEM picture and elemental analysis of a particle collected on 20 April.

than $0.3 \mu \mathrm{m}$ ), a little higher on 22 April than on 20 April, seems to show that the abundance of particles smaller than $0.3 \mu \mathrm{m}$ was not affected by volcanic ash.

Measured concentrations of IN, considering two values of $S_{\text {ice }}$ and $S_{w}$, in aerosol sampled on 20 and 22 April, evidence different behaviours of the sampled aerosol. In fact, while in conditions of subsaturation with respect to water, the concentration are similar for both the 20 and 22 April samples, at supersaturation with respect to both ice $\left(S_{\text {ice }}=20.8 \%\right)$ and water $\left(S_{\mathrm{w}}=0.45 \%\right)$, there is a marked increase of IN for the 20 April sample, and only a moderate increase for the 22 April sample.

Previous measurements performed in a rural area (S.Pietro Capofiume, near Bologna, July 2007) gave a lower IN concentration $\left(704 \mathrm{~m}^{3}\right)$ than the value measured on 20 April. The 20 April filter showed a ratio of $\mathrm{IN}_{\mathrm{TSP}}$ to aerosol number concentration measured with OPC of about 1:110, while in the rural areas the mean value was 1:1700. For the 22 April filter, the ratio was about 1:430. The different behaviour of aerosol at low water supersaturation should indicate some changes in the physical and chemical properties of the particles.

With regard to the elemental composition of aerosol particles, using SEM-EDX observations, it was found that $30 \%$ of the inorganic coarse particles (geometric diameter larger than $1 \mu \mathrm{m}$ ) could be considered to be of volcanic origin on 20 April. Si and Al concentrations were found to be prevalently much higher than the $\mathrm{Ca}$ and $\mathrm{Fe}$ ones. About $28 \%$ of the ash particles examined and about $50 \%$ of the particles with geometric diameter lower than $1 \mu \mathrm{m}$ contained sulphur, probably indicating the adsorption of S-rich particles onto the coarse particles. The small particles in volcanic ash plumes should be typically composed largely of sulphuric acid.

\section{Acknowledgements}

We gratefully acknowledge the collaboration of Mr. F. Corticelli (IMM-CNR) for SEM-EDX observations and the Meteorological Service of the Regional Protection Agency (ARPA-SIMC, Servizio Idro-Meteo-Clima, Bologna). We thank Renato Santangelo and the staff for establishing and maintaining the AERONET Modena site used in this investigation.

\section{References}

[1] A. W. Woods, "Moist convection and the injection of volcanic ash into the atmosphere," Journal of Geophysical Research, Vol. 98, 1993, pp. 17627-17636.

[2] L. S. Glaze, S. M. Baloga, L. Wilson, "Transport of atmospheric water vapour by volcanic eruption columns,"Journal of Geophysical Research, Vol. 102, 1997, pp. 6099-6108.

[3] G. C. Mayberry, W. I. Rose, G. J. S. Bluth, "Dynamics of the volcanic and meteorological clouds produced by the December 26, 1997, eruption of Soufrière Hillsvolcano, Montserrat," W.I. In Druitt, T.; Young, S.; and Kokelaar, P., eds. The 1995-99eruptions of Soufrière Hills Volcano, Montserrat. Geological Society, London, Memoirs, Vol. 21, 2002, pp. 539-555.

[4] W. I. Rose, G. J. S. Bluth, I. M. Watson, "Ice in volcanic clouds: When and Where?" Proceedings of the $2^{\text {nd }}$ International Conference on volcanic ash and aviation safety, OFCM, Washington, DC, Session 3, 2004, pp. 27-33.

[5] L. S. Glaze, S. M. Baloga, L. Wilson, " Transport of atmospheric water vapour by volcanic eruption columns," Journal of Geophysical Research, Vol. 102, 1997, pp. 6099-6108.

[6] T. Koop, B. Luo, A.Tsias, T. Peter, "Water activity as the determinant for homogeneous ice nucleation in aqueous solutions," Nature, Vol. 406, 2000, pp. 611-614.

[7] H. R. Pruppacher, J. D. Klett, "Microphysics of Clouds and Precipitation," Kluwer Academic Publishers, Dordrecht, 1997, pp. 954.

[8] J.Rosinski, "The role of natural and man-made ice-forming nuclei in the atmosphere,"Advances in Colloid and Interface Science, Vol.10, 1979, pp. 315-367.

[9] W.Szyrmer, I.Zawadzki, "Biogenic and anthropogenic sources of ice-forming nuclei: a review,"Bulletin of the 
American Meteorological Society, Vol. 78,1997, pp. 209-228.

[10] K. Isono, K. Komabayasi, A. Ono, "Volcanoes as a source of atmospheric ice nuclei," Nature, Vol. 183, 1959, pp. 317-318.

[11] P.V.Hobbs, C. M. Fullerton, G. C. Bluhm, "Ice nucleus storms in Hawaii," Nature, Vol. 230, 1971, pp. 90-91.

[12] T. Tanaka, "Ice nucleating activity and the mode of action of volcanic ash ejected from Mt.Usu in Hokkaido. -An improved method to remove hygroscopic materials collected on a membrane filter," Papers in Meteorology and Geophysics, Vol. 31, 1980, pp.153-171.

[13] S. Price, J C. Pales, "Ice nucleus counts and variation at $3.4 \mathrm{~km}$ and near sea level in Hawaii," Monthly Weather Review, Vol. 92, 1964, pp. 207-221.

[14] R.F. Pueschel, B. G. Mendonca, "Dispersion into the higher atmosphere of effluent during an eruption of Kilauea volcano," Journal de Récherches atmosphériques, 1972, Vol. 6, pp. 439-446.

[15] R. C. Schnell, A. C. Delany, "Airborne ice nuclei near an active volcano," Nature, Vol. 264, 1976, pp. 535-536.

[16] R. C. Schnell, R. F. Pueschel, D. L. Wellman, "Ice nucleus characteristics of Mount St.Helens effluents," Journal of Geophysical Research, Vol. 87, No.C13, 1982, pp. 11109-11112.

[17] A. J. Durant, R. A. Shaw, W. I. Rose, Y. Mi, G. G. J. Ernst, "Ice nucleation and overseeding of ice in volcanic clouds," Journal of Geophysical Research, Vol. 113, No.D09206, 2008. doi: 10.1029/2007JD009064, 2008

[18] M. Burton, G. Salerno, A. La Spina, A., A. Stefansson, H. S. Kaasalainen., "Gas composition and flux report. Institute of Earth Sciences: Eruption in Eyjafjallajökull 20 March to present," available at: http://www.earthice.hi.is/page/ies EYJO compiled, 2010.

[19] S. A.Carn, A. J. Krueger, N. A. Krotkov, K.Yang, K. Evans, "Tracking volcanic sulfur dioxide clouds for aviation hazard mitigation", Natural Hazards, Vol. 51, 2009, pp.325-343, doi:10.1007/s11069-008-9228-4, 2009.

[20] G. Langer, J. Rodgers, "An experimental study of ice nuclei on membrane filters and other substrata," Journal of Applied Meteorology, Vol.14, 1975, pp. 560-571.

[21] C. Gueymard, "Assessment of the accuracy and computing speed of simplified saturation vapour equations using a new reference dataset," Journal of Applied Meteorology, Vol. 32, 1993, pp. 1294-1300.

[22] G. Santachiara, L. Di Matteo, F. Prodi, F. Belosi, “Atmospheric particles acting as Ice Forming Nuclei in different size ranges," Atmospheric Research, Vol. 96, 2010, pp. 266-272.

[23] H. Flentje, H. Claude, T. Elste, S. Gilge, U. Köhler, C. Plass-Dülmer, W. Steinbrecht, W. Thomas, A. Werner, W. Fricke, "The Eyjafjallajökull eruption in April 2010 detection of volcanic plume using in-situ measurements, ozone sondes and lidar-ceilometer profiles," Atmospheric Chemistry and Physics, Vol. 10, 2010, pp.10085-10092.

[24] G. Pappalardo, I. Mattis, and the EARLINET team, "Dispersion and evolution of the Eyjafjallajokull ash plume over Europe: vertically resolved measurements with the European LIDAR network EARLINET ESA/EUMETSAT,"ESA/EUMETSAT Workshop on Volcanic Ash Monitoring, ESRIN, Frascati, Italy, May 26-27, 2010.

[25] D. Brunner, "In-situ, lidar, sonde and aircraft observations of volcanic ash in Switzerland," ESA/EUMETSAT Workshop on Volcanic Ash Monitoring, ESRIN, Frascati, Italy, May 26-27, 2010.

[26] F. Prodi, G. Santachiara, V. Prodi, "A study of the effect of size on ice nucleation in the aerodynamic range of particles," Journal of Applied Meteorology, Vol. 21, 1982, pp. 945-952.

[27] C. Rolf, M. Krämer, C. Schiller, “Ground based LIDAR observations of the Eyjafjalla ash cloud over Jülich, Germany," International Aerosol Conference, Helsinki, 2010.

[28] W. I. Rose, "Scavenging of volcanic aerosol by ash: atmospheric and volcanologic implications," Geology, Vol. 5, 1977, pp. 621-624.

[29] W. I. Rose, R. L. Chuan, R. D. Cadle, D. C. Wods, "Small particles in volcanic eruption clouds,"American Journal of Science, Vol. 280, 1980, pp. 671-696.

[30] C. S. Witham, C. Oppenheimer, C. J. Horwell, "Volcanic ash-leachates: a review and recommenddations for sampling methods," Journal of Volcanology and Geothermal Research, Vol. 141, 2005, pp. 299-326. 